\title{
A revised numerical model for parachute inflation based on ALE method
}

\author{
DOI: 10.35530/IT.071.06.1708
}

CHEN CHEN

PENG SUN

QILEI GUO

\section{ABSTRACT - REZUMAT}

\section{A revised numerical model for parachute inflation based on ALE method}

The parachute inflation process is a typical time-varying, non-linear and fluid-structure coupling problem, especially in airdrop condition. For its complexity, numerical model of the inflation process is a big challenge, and most of the models established before still have room for improvement. There were two common problems that the first one was ignorance of inertia force of canopy and line, and the second was that took stretch speed as the initial airdrop speed in modelling. Thus, a modified finite element model for canopy inflation process based on ALE (Arbitrary Lagrange Euler) method was established that the inertia force of canopy and line was taken into consideration and the initial airdrop speed was estimated and adjusted. The opening load in finite mass situation during deployment-inflation process of C-9 type parachute was calculated. The result was compared to experimental data and calculated data of unmodified models. It was indicated that the opening load and peak time of modified model was the closest to experiment and the snatch load was also calculated and confirmed, so that the correctness and rationality of the model was verified. Then the factor influence of inertia force and initial airdrop speed was analysed, which provided a reference for parachute numerical modelling.

Keywords: ALE, parachute, inflation, finite mass, finite element model

\section{Un model numeric revizuit pentru umflarea parașutelor bazat pe metoda ALE}

Procesul de umflare a parașutei este o problemă tipică de cuplare neliniară și cu structură fluid, care variază în timp, în special în momentul deschiderii parașutei. Prin complexitatea sa, modelul numeric al procesului de umflare reprezintă o provocare, iar majoritatea modelelor stabilite anterior pot fi încă îmbunătățte. Au existat două probleme: prima a fost ignorarea forței de inerție a voalurii și a suspantelor, iar a doua a fost aceea că viteza de întindere a fost considerată, în modelare, ca viteză inițială de lansare. Astfel, a fost stabilit un model de element finit modificat pentru procesul de umflare a voalurii bazat pe metoda ALE (Arbitrary Lagrange Euler), care ia în considerare forța de inerție a voalurii și a suspantelor, iar viteza de lansare inițială a fost estimată și ajustată. S-au calculat solicitările la deschidere, în situația de masă finită, din timpul procesului de desfășurare-umflare pentru o parașută de tip C-9. Rezultatul a fost comparat cu datele experimentale și datele calculate ale modelelor nemodificate. Se indică solicitarea la deschidere și timpul maxim pentru modelul modificat ca fiind cele mai apropiate de datele experimentale, iar solicitarea la aterizare a fost, de asemenea, calculată și confirmată, astfel încât corectitudinea și raționalitatea modelului au fost verificate. Apoi a fost analizată influența factorului forței de inerție și a vitezei de lansare inițiale, care a furnizat o referință pentru modelarea numerică a parașutei.

Cuvinte-cheie: ALE, parașută, umflare, masă finită, model cu element finit

\section{INTRODUCTION}

The parachute numerical inflation model of airdrop situation has long been focused. However, the inflow and canopy structure changes sharply in a short time which is a complex non-linear problem and the fluid-structure coupling model also couples with the ballistic equation of the parachute system, which was difficult to solve. Tutt first established a deploymentinflation airdrop model by finite mass and dynamic mesh method [1], which was verified through experimental comparison. Gao established a slotted parachute model by ALE method [2] and the adaptive mesh technology in airdrop situation, calculated the drag coefficients and analysed the influence of initial airdrop speed. Cheng calculated the opening process in a finite mass situation [3-5], and analysed the interrelation between dangerous section, overload and canopy shape.
The above researches laid a solid foundation for numerical calculation of parachute airdrop FSI (Fluid Structure Interaction) problem. However, most of the calculation models still have room for improvement, such as models neglected fabric porosity and using infinite mass method to calculate airdrop situation. Two more common problems are: first, assumed that the canopy was initially straightened and the stretch speed was the initial airdrop speed. Yet actually, there is no initial stress on line. Second, most studies ignored the gravity of canopy and line. However, the inertia force caused by canopy and line is not negligible.

In order to improve the accuracy of numerical calculation, a finite element model of parachute inflation, which fabric permeability considered, inertia force of canopy and line calculated and initial airdrop speed modified, was established based on ALE method. 
The opening load of C-9 parachute was calculated in infinite mass situation, which was compared to experiment and unmodified model data.

\section{MATHEMATICS MODEL}

\section{Governing equations}

ALE equation was used to solve free interface flow and typical fluid-solid coupling problems. The structure and flow field were coupled by penalty function. While $\Omega^{s}$ denotes the canopy structural domain and $\partial \Omega^{s}$ is the solid boundary, the governing equation is [6]:

$$
\rho^{s}\left(\frac{d^{2} \boldsymbol{y}}{d t^{2}}-\boldsymbol{f}\right)-\operatorname{div} \sigma^{s}=0 \text { on } \partial \Omega^{s}
$$

where $\boldsymbol{y}$ is displacement, $\rho^{s}-$ density of structure, $\boldsymbol{f}-$ volume force acting on structure, $\sigma^{s}$ - Cauchy stress, $t$ - integral time.

The compressibility of air was neglected for the dropping velocity was less than $0.3 \mathrm{Ma}$. The time-varying unsteady incompressible $\mathrm{N}-\mathrm{S}$ equations under reference coordinates are:

$$
\begin{gathered}
\frac{\partial \rho^{f}}{\partial t}+\rho^{f} \cdot \operatorname{div} \boldsymbol{u}+(\boldsymbol{u}-\boldsymbol{w}) \operatorname{grad} \rho^{f}=0 \\
\rho^{f} \frac{\partial \boldsymbol{u}}{\partial t}+\rho^{f}(\boldsymbol{u}-\boldsymbol{w}) \operatorname{grad} \boldsymbol{u}=\operatorname{div} \sigma^{f}+\boldsymbol{f} \\
\rho^{\mathrm{f}} \frac{\partial e}{\partial t}+\rho^{\mathrm{f}}(\boldsymbol{u}-\boldsymbol{w}) \operatorname{grad} e=\sigma^{\mathrm{f}} \cdot \operatorname{grad} \mathbf{u}+\boldsymbol{f} \cdot \boldsymbol{u}
\end{gathered}
$$

where $\boldsymbol{u}$ is particle velocity, $\boldsymbol{w}$ - mesh velocity of reference coordinate, $\rho^{f}-$ the density of fluid, $e-$ the internal energy of material.

The Dirichlet and Neumann boundary conditions are:

$$
\boldsymbol{u}=g(t) \text { on } \partial \Omega_{1}^{f} \text { and } \tau^{f} \cdot \sigma^{f}=\boldsymbol{h}(t) \text { on } \partial \Omega_{2}^{f}
$$

where $\partial \Omega_{1}^{f}$ is the boundary of fluid, $g(t)$ - the function of boundary inflow velocity, $\partial \Omega_{2}^{f}$ - the traction boundary and $\tau^{f}-$ its unit normal, $\boldsymbol{h}(t)$ - the stress potential function.

\section{Initial airdrop speed}

During deployment, when the relative velocity of canopy and payload is zero, the viscoelastic deformation of line absorbed all the kinetic energy and whose instantaneous axial tension load reaches peak, that is, the snatch load, and the corresponding speed of canopy/payload is the stretch speed. Which obviously, not equal to initial airdrop speed.

The initial airdrop speed can be estimated based on Wolf's experience method [7]:

$$
\begin{gathered}
\frac{\Delta v_{\max }}{v_{0}}=\mathrm{f} \cdot\left[\frac{\rho\left(\mathrm{C}_{\mathrm{D}} \mathrm{S}\right)_{\mathrm{p}} I_{1}}{2 m_{\mathrm{p}}}\right] \\
m_{\mathrm{p}}=m_{\mathrm{c}}+\frac{m_{1}}{2} \\
K_{b}=\frac{I_{1} g}{v_{0}^{2}}-\frac{\rho \mathrm{C}_{\mathrm{D}} A I_{1}}{2 m_{\mathrm{b}}} \cdot\left(\frac{v_{\mathrm{b}}}{v_{0}}\right)^{2}
\end{gathered}
$$

where $v_{0}, v_{\mathrm{b}}, \Delta v$ are the speed of initial airdrop, payload at the line stretched, and relative speed of canopy and payload, $f-$ the slope of fitting curve, $\rho-$ density of air, $\left(C_{D} S\right)_{p}$ - the resistance area of canopy, $I_{1}$ - the initial length of line, $m_{\mathrm{p}}, m_{\mathrm{c}}, m_{1}, m_{\mathrm{b}}$ - the mass of parachute, canopy, line and payload, $K_{b}-a$ working conditions coefficient, $C_{D} A-$ the resistance area of payload.

The initial airdrop velocity estimated may slightly deviated due to factors like parachute type, strop and mass distribution.

\section{COMPUTATION MODEL SETUP}

The full-scale numerical model of C-9 parachute was established and the airdrop-deployment-inflation process calculated. The model parameters were shown in table 1.

The packed model mesh was shown in figure 1. The canopy was discretized by two-dimension unstructured shell grid, and structured for payload [2]. The line was not fully straightened, while no initial stress. The fluid domain, shown in figure 1, was established for airdrop process in finite mass situation. The mesh nearby canopy was densified for efficiency.

Working conditions in still air: The airdrop angle was $90^{\circ}$, the stretch speed was $76.2 \mathrm{~m} / \mathrm{s}$, the stretch altitude was $3962.4 \mathrm{~m}$, and mass of payload was $98.88 \mathrm{~kg}$.

Four calculation models (table 2) were established and calculated for comparison.

Second-order Van Leer MUSCL advection algorithm was adopted to solve the governing equations with permeability calculated $[8,9]$ based on explicit finite element method.

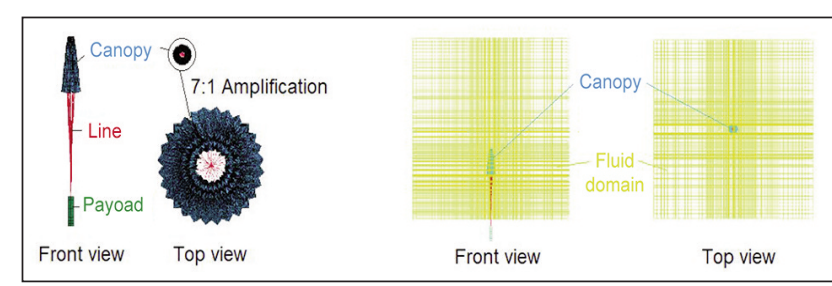

Fig. 1. 3D mesh model of initial packed parachute and its fluid mesh domain

MODEL PARAMETERS OF C-9 PARACHUTE

\begin{tabular}{|c|c|c|c|c|c|c|c|}
\hline $\begin{array}{c}\text { Canopy } \\
\text { gore }\end{array}$ & $\begin{array}{c}\text { Nominal } \\
\text { diameter } \\
(\mathbf{m})\end{array}$ & $\begin{array}{c}\text { Vent } \\
\text { diameter } \\
(\mathbf{m})\end{array}$ & $\begin{array}{c}\text { Line } \\
\text { length } \\
(\mathbf{m})\end{array}$ & $\begin{array}{c}\text { Canopy elastic } \\
\text { modulus } \\
(\mathbf{P a})\end{array}$ & $\begin{array}{c}\text { Canopy } \\
\text { thickness }(\mathbf{m})\end{array}$ & $\begin{array}{c}\text { Line elastic } \\
\text { modulus } \mathbf{( P a )}\end{array}$ & $\begin{array}{c}\text { Parachute } \\
\text { mass } \\
(\mathbf{k g})\end{array}$ \\
\hline 28 & 8.5 & 0.85 & 7 & $4.38 \mathrm{e} 8$ & $1 \mathrm{e}-4$ & $9.7 \mathrm{e} 10$ & 5.126 \\
\hline
\end{tabular}




\begin{tabular}{|c|c|c|}
\hline \multicolumn{3}{|c|}{ PARAMETERS OF CALCULATION MODELS } \\
\hline Model & $\begin{array}{c}\text { Initial airdrop } \\
\text { speed }\left(\mathbf{v}_{\mathbf{0}} / \mathbf{m} / \mathbf{s}\right)\end{array}$ & $\begin{array}{c}\text { Gravity of canopy } \\
\text { and line }\end{array}$ \\
\hline Model1 & 80 & Calculated \\
\hline Model2 & 80 & Not calculated \\
\hline Model3 & 76.2 & Calculated \\
\hline Model4 & 76.2 & Not calculated \\
\hline
\end{tabular}

\begin{tabular}{|c|c|c|c|c|}
\hline \multicolumn{5}{|c|}{ RELATIVE ERRORS OF PEAK TIME AND } \\
PEAK VALUES \\
\hline Model & $\begin{array}{c}\mathbf{1}^{\text {st }} \text { peak } \\
\text { time (\%) }\end{array}$ & $\begin{array}{c}\mathbf{1}^{\text {st }} \text { peak } \\
\text { value (\%) }\end{array}$ & $\begin{array}{c}\mathbf{2}^{\text {nd }} \text { peak } \\
\text { time (\%) }\end{array}$ & $\begin{array}{c}\mathbf{2}^{\text {nd }} \text { peak } \\
\text { value (\%) }\end{array}$ \\
\hline Model1 & 7.69 & 10.43 & 2.34 & 10.22 \\
\hline Model2 & 21.76 & 27.83 & 7.96 & 13.98 \\
\hline Model3 & 18.24 & 42.61 & 3.72 & 5.38 \\
\hline Model4 & 18.68 & 5.22 & 3.08 & 2.15 \\
\hline
\end{tabular}

\section{COMPARASION AND ANALYZE}

The opening load of the calculated and airdrop experimental data [7] were shown in figure 2. $F$ denoted the opening load, $W_{\mathrm{b}}$ was gravity of payload, $t_{\mathrm{f}}$ was canopy inflation time.

Seen from figure 2 , the calculated curves were mainly in good agreement with experiment: The shape of curves was similar; the opening time was almost the same; the load curve had two peaks, whose occurrence time (peak time) nearly identical. However, due to omission of damping dissipation and friction of canopy, the calculated loads were larger and peak time ahead of experiment. The relative errors were shown in table 3.

In case of Model 1 and Model2, $v_{0}$ was $80 \mathrm{~m} / \mathrm{s}$, Model1 calculated gravity (inertia force) of canopy and line while Model2 did not. Affected by inertia force and interaction among canopy, line and payload, the load curve of Model1 fluctuated. And the opening shape of canopy changed: the two peak values of opening load $(10.43 \%$ and $10.22 \%$ larger) were less than Model2 (27.83\% and $13.98 \%$ larger) and the peak time delayed, which was more accurate.

In case of Model1 and Model3, the inertia force was calculated. $v_{0}$ of Model 1 was $80 \mathrm{~m} / \mathrm{s}$ while $76.2 \mathrm{~m} / \mathrm{s}$ of Model3, which was, took stretch speed as $v_{0}$ by traditional modelling method. The stretch time and load were the same of the two models. For Model1 after stretching, the airflow speed was lager and incensement of opening load faster due to higher initial velocity. Because of associated air mass and formation of apex vortexes, the $1^{\text {st }}$ peak fluctuated several times and appeared later, only $7.69 \%$ ahead while $18.24 \%$ of Model3. With larger initial kinetic energy, the $2^{\text {nd }}$ peak of Model 1 was larger than Model 3 while the peak time was similar.

In case of Model2 and Model4, the inertia force was omitted. $v_{0}$ of Model 2 was $80 \mathrm{~m} / \mathrm{s}$, while $76.2 \mathrm{~m} / \mathrm{s}$ for Model4. Due to larger initial speed and neglect of inertia force, two peaks of Model2 were obviously ahead of experiment and Model4. For larger kinetic energy, two peaks of Model2 were also larger, while Model 4 was more realistic relatively.

In case of Model 3 and Model4, $v_{0}$ was $76.2 \mathrm{~m} / \mathrm{s}$, Model 3 calculated inertia force while Model 4 did not. Due to influence of inertia force, the two curves differed greatly at the $1^{\text {st }}$ peak and then tended to be

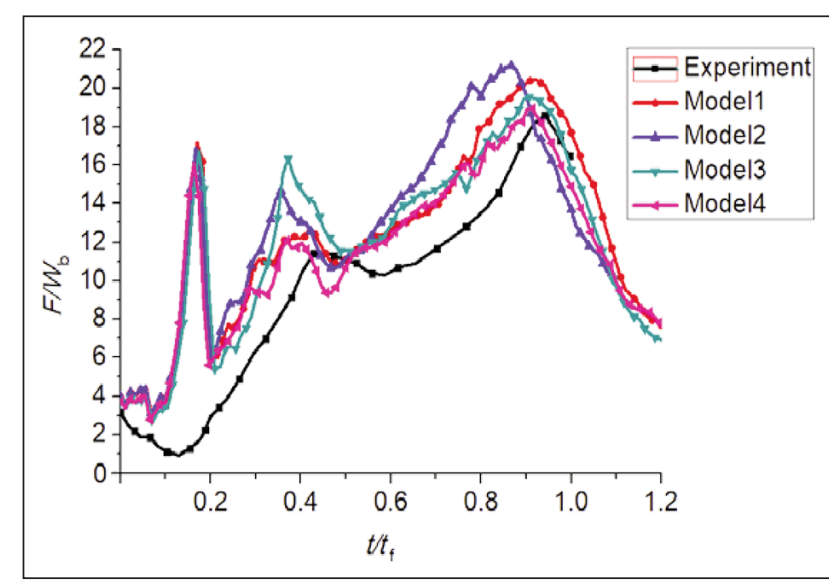

Fig. 2. Curves of opening load

similar. After deployment, the incensement of opening load of Model 3 was faster and the $1^{\text {st }}$ peak larger while the peak time was slightly delayed compared to Model4. And then the changing trend of curves were almost the same, that was, similar $2^{\text {nd }}$ peak time while peak value of Model 3 was slightly larger.

To sum up, neither the initial airdrop speed $v_{0}$ nor the inertia force affected the law of opening load alone, but the combination made a certain impact. When $v_{0}$ increased (higher than stretch speed) and inertia force calculated (Model1), the law of opening load was the closest to experiment that with similar curve shape and accurate peak time, although the peak value was larger. When the stretch speed was taken as $v_{0}$ and inertia force ignored (Model4), the peak time was much earlier but the value closer to experiment. Increasing $v_{0}$ (Model2) or calculated inertia force alone (Model3) tended to cause a stronger single factor influence, that led to larger opening force, earlier peak time and low accuracy than the former two models.

In addition, there was an obvious difference between the calculated and experimental curves: At the moment $t / t_{\mathrm{f}}=0.17$, an obvious impact load acted on the calculated curves while the experimental one without. This was just the calculation of snatch load. For a finished parachute, pilot parachutes or bags had been designed to counteract the violent impact of stretching, yet was omitted in numerical modelling. In another experiment (experiment1) [7], the curve of opening load with snatch load included was given in figure 3. For the unclearness of experimental condition, 


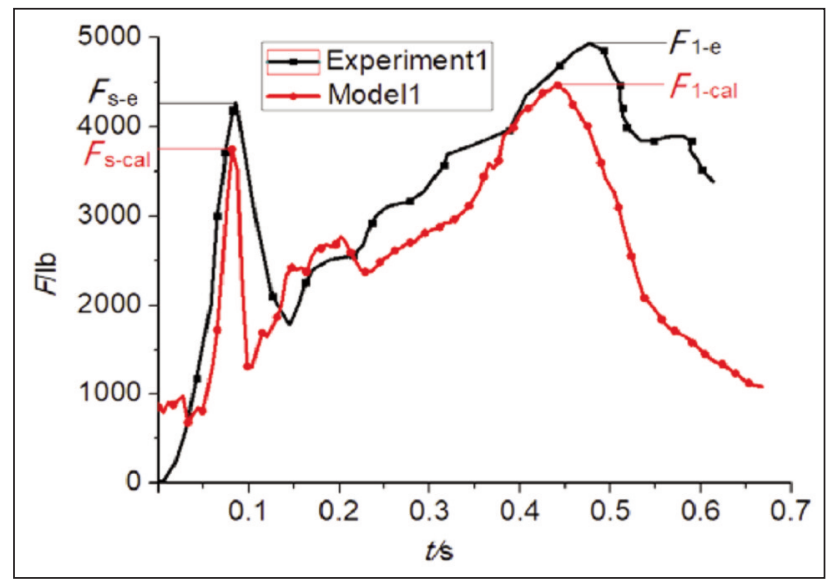

Fig. 3. Curve of snatch and opening load

only the changing trend and peak value was to be referenced.

From figure 3, $F_{\text {s-e }} / F_{1-\mathrm{e}}=0.86$ in experiment1 while $\mathrm{F}_{\text {s-cal }} / \mathrm{F}_{1 \text {-cal }}=0.84$ in calculation, the relative error was only $3.49 \%$. This also helped to prove the correctness of snatch load and opening load in modelling and calculation.

\section{CONCLUSIONS}

A revised deployment-inflation finite element model of parachute based on ALE method in finite mass situation was built. C-9 parachute was taken as an example to validate the accuracy and reliability of the model compared to traditional ones by opening load of canopy. And the following conclusions were drawn:

- The modified model was able to predict the opening process accurately. The changing curve of opening load was the closet to experiment that the peak time was accurate but the value larger, however, met the engineering accuracy requirements.

- Neither the inertia force of canopy and line nor the initial airdrop speed affected the changing law of opening force alone. When the stretch speed was taken as initial airdrop speed while inertia force neglected, the peak time was much advanced but value closest to experiment. Relatively, increasing the initial airdrop speed or calculated inertia force alone tended to gain low accuracy.

- The initial airdrop speed and inertia force had little effect on the deployment process that the stretch time and load were almost independent of these two factors.

\section{ACKNOLEDGEMENTS}

The authors wish to thank the program of "Study on Failure Mechanism of APS Folding-Opening Process (18ZB0688)" and "Sichuan Science and Technology Program (No. 2018JY0177)" for funding for this Research Group.

\title{
REFERENCES
}

[1] Tutt, B., Roland, S., Finite mass simulation techniques in LS-dyna. In: $21^{\text {st }}$ AIAAAerodynamic Decelerator Systems Technology Conference and Seminar 23-26 May 2011, Dublin, Ireland

[2] Gao, X., Zhang, Q., et al., Numerical simulation on finite mass inflation dynamics of parachute. In: Journal of National University of Defense Technology, 2016, 38, 4, 185-190

[3] Cheng, H., Yu, L., Yang, X., et al., Numerical simulation of parachute opening process in finite mass simulation. In: Acta Aerodynamica Sinica, 2014, 32, 2, 258-263

[4] Yu, L., Cheng, H., Zhan, Y., Li, S., Study of parachute inflation process using fluid-structure interaction method, In: Chinese journal of Aeronautics, 2014, 27, 2, 272279

[5] Sun, Z., Cheng, H., Yang, J., Numerical study of extra-large parachute's pre-inflation in finite mass situation. In: Autex Research Journal, 2018, 18, 2, 130-136

[6] Gao, X., Tang, Q., et al., Numerical study of fluid-structure interaction of slot-parachute's inflation process. In: Acta Aerodynamica Sinica, 2013, 34, 10, 2265-2276

[7] Ewing, E.G., Knacke, T.W., Bixby, H.W., Recovery systems design guide, Wu J.P., translated. Beijing: Aviation Industry Press, 1988, 219-234

[8] Gao, X., Gao, Q., et al., A study on the slots-parachute inflation based on ALE method. In: Spacecraft recovery and remote sensing, 2013, 34, 1, 13-20

[9] Jia, H., Rong, W., et al., The use of LS-DYNA to simulate the permeability parameters of the parachute canopy. In: Spacecraft recovery and remote sensing, 2009, 30, 1, 15-20

Authors:

\section{CHEN CHEN, QILEI GUO, PENG SUN}

Civil Aviation Flight University of China, Aviation Engineering Institute, Nanchang Street, no. 46, Guang Han, 618307, Si Chuan, China e-mail: cafuc_guoql@outlook.com, stewen1981@163.com

\author{
Corresponding author: \\ CHEN CHEN \\ e-mail: chenchen_echo@163.com
}

